\title{
FRIEDRICH NIETZSCHE EN EL PENSAMIENTO DE RENÉ GIRARD
}

\author{
PABLO RUIZ LOZANO
}

Facultad de Teología de Granada

\begin{abstract}
RESUMEN: René Girard es un antropólogo, que ha propuesto una original hipótesis acerca del mecanismo del chivo expiatorio y la relación entre violencia y religión. A partir de ella intenta realizar una crítica de la modernidad, buscando recuperar el papel del cristianismo en la cultura. Desde esta perspectiva, se acerca a la obra de F. Nietzsche mostrando las dos caras que descubre en este pensador: su intuición sobre la verdad oculta de la violencia; y su rechazo de esta verdad para volver a los orígenes violentos de la cultura.
\end{abstract}

PALABRAS CLAVE: mecanismo del chivo expiatorio, Nietzsche, cristianismo, violencia, R. Girard.

\section{Friedrich Nietzsche in Rene Girard's Thought}

ABSTRACT: René Girard is an anthropologist, who has proposed an original hypothesis about the scapegoat mechanism and the relation between violence and religion. Starting from it he intends to work out a criticism of modernity, seeking out to recuperate the role of Christianity in the culture. From this perspective, he approaches the work of F. Nietzsche showing the two faces he finds out in the thinker: his intuition about the hidden truth of violence; and his rejection of this truth, to return to the violent origins of culture.

KEY WORDS: scapegoat mechanism, Nietzsche, Christianity, violence, R. Girard.

\section{INTRODUCCIÓN}

Establecer una relación entre la obra de René Girard y la filosofía no siempre ha resultado fácil. La singularidad del pensamiento de éste, a caballo entre la literatura, la antropología, la psicología y otras ciencias, hace que no todo el mundo le reconozca un espacio en el horizonte filosófico. Sin embargo, como bien ha mostrado Guido Vanheeswijck en su artículo sobre la filosofía en René Girard, son diversas las influencias que se pueden encontrar en su pensamiento ${ }^{1}$. Y tan sólo en España ya se han realizado y se siguen realizando diversas tesis doctorales en filosofía acerca de este autor ${ }^{2}$.

Una de las claves de comprensión del pensamiento de René Girard es su crítica al pensamiento de los últimos siglos por su carácter antirreligioso y poco integral en su concepción antropológica. Esto le ha llevado a postular una

1 Vanheeeswisck, G., «El lugar de René Girard en la filosofía contemporánea»: Anthropos. Huellas del conocimiento 213 (2006) 41-56. El artículo es un interesante referente para conocer posibles relaciones entre el pensamiento de Girard y la filosofía, pero se podrían establecer otras relaciones a las que el autor no hace referencia.

2 El pasado diciembre de 2012 se presentó una magnífica tesis en la facultad de filosofía de la Universidad de Granada, titulada La evaluación de la modernidad en la teoría mimética de René Girard. Deseo, violencia, religión y libertad, cuyo autor es Moreno Fernández, A. 
antropología en la que la religión es presupuesto imprescindible para una adecuada interpretación del hombre. De ahí que entre las dificultades que plantea la obra de Girard sea que su abordaje filosófico explícito no es al uso ${ }^{3}$. Los filósofos que el francés cita en su obra suelen aparecer con el objetivo de refrendar su hipótesis. Es cierto que existen algunas excepciones, pensadores con los que dialoga, pero en estos casos, normalmente, lo hace también desde el particular prisma de su hipótesis victimaria. Entre los filósofos con los que establece un diálogo más enriquecedor y sugerente, a la vez que desconcertante, está F. Nietzsche; aunque, como veremos, el modo en que lo analiza es tan singular, como es el mismo pensamiento del francés. Con todo, la lectura particular que Girard realiza de éste resulta todo un reto para el que desea reflexionar sobre cuestiones candentes en el pensamiento filosófico de este tiempo.

En la obra de Girard, Nietzsche es uno de los pensadores más citados: además de las múltiples referencias a éste diseminadas a lo largo de sus escritos, Girard le ha dedicado varios artículos ${ }^{4}$. A diferencia de lo que ocurre con el pensamiento de Marx, cuyo interés para el francés se queda en su crítica a la religión, la filosofía y la vida de Nietzsche resultan más atractivas desde la perspectiva girardiana, pues ambas dimensiones son susceptibles de ser vistas a la luz de la hipótesis expiatoria. Para Girard, Nietzsche resulta un caso singular en la filosofía, ya que la confrontación con el pensamiento del germano desvela con nitidez la eficacia deconstructiva de la hipótesis mimética. Toda la problemática relacional humana de la vida de Nietzsche se acaba reflejando en su obra y esto permite al pensamiento de Girard convertirse en un hábil instrumento para diseccionar las claves de comprensión del pensamiento nietzscheano.

Por ello, en este trabajo intentaremos seguir la perspectiva trazada por la investigación de Girard para llegar, eso sí, a comprender qué diálogo se puede establecer entre ambos.

3 Otra cuestión son los posibles referentes implícitos con los que el autor puede estar dialogando y con los que es frecuente que lo haga en un horizonte más filosófico.

4 GIRARD, R., "Superman in the Underground: Strategies of Madness - Nietzsche, Wagner and Dostoyevski»: Modern Language Notes 91 (1976) 1161-1185. Reeditado en ID, To Double Business Bound: Essay on literature and Anthropology, The Johns Hopkins University Press, Baltimore and London, 1978 (ed. Castellano: ID, Literatura, Mimesis, Antropología, Gedisa, Barcelona 1997, 74-94). ID, «Dionysus versus the Crucified»: Modern Language Notes 99 (1984) 816-835. Artículo reeditado en ID, The Girard Reader, Crossroad, New York 1996, 244261. En castellano ha sido publicado (traducción de Ángel Barahona) en Religión y Cultura XLV (1999), 13-34. Las citas de este artículo se referirán a las páginas de la edición de The Girard Reader y entre paréntesis a la traducción castellana. ID, «Le meurtre fondateur dans la pensée de Nietzsche», en: Dumouchel, P. (dir.), Colloque de Cerisy. Violence et Vérité. Autour de René Girard, Grasset, Paris 1985, 597-613. GIRARD, R., «Nietzsche and contradiction»: Stanford Italian Review 6, 1-2 (1986) 53-65. Reeditado en ID, La Conversión de l'art, Carnets Nord, Paris 2008, 127-146. ID, Je vois Satan tomber comme l'eclair, Grasset, Paris 1999, 263-279; en castellano: Id, Veo a Satán caer como el relámpago, Anagrama, Barcelona 2002, 221-234. Tanto para estas obras como para otras de Girard que estén traducidas al castellano, citaré las páginas del original y entre paréntesis las páginas de la versión castellana. 
Antes de iniciar el análisis, será imprescindible aclarar algunos conceptos que son necesarios para entender los presupuestos de René Girard; a continuación, veremos cómo Girard considera fundamental la experiencia vital de la persona de Nietzsche como factor de comprensión de su obra; seguiremos, después, con la relación entre la concepción de la religión nietzscheana y la hipótesis victimaria; y acabaremos, finalmente, con una reflexión en la que intentaremos aclarar hacia donde nos ha llevado nuestro autor en su investigación.

\section{Prolegómenos}

Para comprender el pensamiento de Girard hay que detenerse en tres conceptos básicos de su pensamiento: mimesis, mecanismo del chivo expiatorio y religión.

\subsection{Mimesis}

El trabajo intelectual de René Girard se inicia con el análisis de algunas de las grandes obras de la literatura, en las que descubre una común comprensión antropológica. El autor francés encuentra en ellas un saber respecto a las relaciones humanas, que engloba bajo el concepto de «mimesis», con el cual hace referencia a las dinámicas del comportamiento humano. Para nuestro autor, a través de los personajes literarios se percibe una concepción del ser humano que manifiesta las profundas huellas de una dinámica interdividual ${ }^{5}$ basada en lo que él llama el deseo mimético. Lo sorprendente y particular de esta noción es que en manos de Girard muestra una gran fecundidad explicativa desde un punto de vista psicológico, pero también resulta un principio operativo capaz de explicar tanto el mundo relacional humano, como el conjunto de la cultura y la historia. La mimesis se transforma, en el pensamiento girardiano, en un concepto clave para la construcción de una antropología revolucionaria, por lo que tiene de innovadora y atrevida.

Sin embargo, la mimesis no es un concepto novedoso en la filosofía. Desde los orígenes de ésta ya se había utilizado el término, si bien se había circunscrito al ámbito de lo imitación representativa. En el caso del francés, el uso del concepto se reelabora para devolverlo a sus orígenes, que cree que está en el mundo interrelacional animal. Así, entiende que la mimesis o deseo mimético es un comportamiento no consciente de imitación de otro individuo, mediante el cual se copia el deseo de ese sujeto con el fin de obtener el objeto deseado por él.

\footnotetext{
5 Girard denomina a la psicología, analizada bajo los principios de la mimesis, con el término «interdividual» (Cf. GIRARD, R., Des Choses cachées depuisla fondation du monde, Grasset, Paris 1978; en castellano: ID, El misterio de nuestro mundo, Sígueme, Salamanca 1982, Tercera Parte). El concepto, creemos, podría ser equivalente a interpersonal. Suponemos que no utiliza este último calificativo para que no se confunda con otras filosofías o psicologías. Algunos intérpretes de lengua castellana han utilizado el término interindividual, nosotros preferimos mantener el término original, que, además, en la versión castellana permanece.
} 
Por lo tanto, mimesis hace referencia al modo como deseamos. Frente a lo que ha afirmado siempre la modernidad, en el hombre no hay un deseo espontáneo, nacido en el interior del sujeto deseante, sino que el deseo aparece porque hay otro sujeto, llamado modelo, que está deseando antes, y al cual se le imita $^{6}$. La importancia que tiene la mimesis es que cuando dos sujetos desean el mismo objeto, es probable que se plantee un conflicto para dirimir quién se queda con él. El encuentro del sujeto y el modelo ante el mismo objeto plantea un problema de difícil resolución: ¿cuál de los dos se quedará con el objeto deseado? Este problema convierte a la mimesis en una relación conflictiva que necesita algún modo de salida.

Precisamente en la manera de solucionar el conflicto está la diferencia entre animales - especialmente, los más cercanos al hombre-y el ser humano, pues según Girard la mimesis no es específica del ser humano, sino que es un modo de comportamiento común a muchos animales. Se podría decir que es la manera natural de incorporarse a la vida de todo animal, pues es la base de cualquier aprendizaje: el modo como se aprende qué se debe desear. Pero en los animales es la propia naturaleza instintiva la que resuelve el problema del conflicto, ya que posee estructuras jerárquicas, de dominancia, que evitan que la violencia pueda llegar hasta puntos extremos ${ }^{7}$. En el caso de los hombres, el problema es más complejo.

Pero antes de describir la deriva antropológica de la mimesis conflictiva, debemos señalar que no siempre el deseo conlleva conflicto. En la mimesis no adquisitiva, el sujeto puede desear sin crear conflicto, pues el modelo se halla a tal distancia (ya sea por razones físicas, de jerarquía social o similar) que la imitación del deseo no supone una amenaza para el mediador o modelo ${ }^{8}$. Si seguimos los ejemplos literarios que Girard nos ofrece, se puede ver que tanto en Don Quijote, como en Sancho, la imitación del deseo se realiza tomando como mediador un modelo externo. El mediador del hidalgo será Amadís de Gaula,

6 En algunos momentos Girard también utiliza el concepto de mediador.

7 El concepto utilizado por René Girard es el «dominance patterns». Con ello se refiere a aquellas estructuras de relación jerárquica que se establece de manera instintiva en los animales y que permite que habiendo el dominio de un miembro o varios de un grupo sobre el resto, no se entable constantemente una lucha por la posición en el grupo. Lo cual permite que una vez se ha resuelto la relación haya una cierta estabilidad en el grupo, al menos hasta que uno de los inferiores se sienta capaz de ponerla en cuestión. Cf. GIRARD, R., Des Choses cachées depuis la fondation du monde, Grasset, Paris 1978, 98-102 (102-107).

8 Además de los casos de mediación externa, se incluye en esta mimesis el comportamiento más adecuado para el aprendizaje o la educación. Incluimos en ésta mimesis lo que Girard sugiere como mimesis de la conversión que sería una mimesis positiva en la que el sujeto renuncia a la violencia a favor del bien. Para llegar a esta renuncia habría que pasar por una comprensión de todo el proceso de la mimesis. Girard no es muy sistemático en la clarificación del concepto mimesis, que a veces parece confundirse con el deseo. Sobre esta cuestión ha profundizado en una muy interesante tesis Moreno Fernández, A., La evolución de la modernidad en la teoría mimética de René Girard. Deseo, Violencia, Religión y libertad, defendida en la Universidad de Granada en diciembre de 2012. 
personaje de las novelas de caballería y que pertenece al mundo de la ficción ${ }^{9}$. En cambio, el caso de Sancho es más singular porque sus deseos vienen mediados por el caballero andante, su señor, con el que comparte las aventuras. Podríamos suponer que la distancia aquí no existe, pues recorren La Mancha uno junto al otro. Pero existe otra distancia que no es física, sino la social. Sancho no puede aspirar a pertenecer al estadio social de Don Quijote. En otro ejemplo, Emma Bovary, el personaje de la novela de Flaubert, copia su deseo de las heroínas románticas que conoce a través de sus lecturas. Estas heroínas se encuentran a mucha distancia de Mme. Bovary, pues pertenecen al mundo de la novela. Y aunque en París haya mujeres como las heroínas románticas, están muy lejos de la vida de provincias que el personaje lleva ${ }^{10}$.

Para este trabajo nos interesa lo que Girard denomina la mimesis de adquisición o de apropiación, en la que surge el enfrentamiento. El proceso de esta mimesis viene regido por las diferentes reacciones que tanto sujeto como modelo adoptan en el conflicto que surge por la posesión del objeto del deseo. El conflicto no es debido sólo a la lucha directa por el objeto, sino también a un efecto consiguiente, que Girard denomina el «double bind $»^{11}$ o doble imperativo contradictorio: cuando el sujeto capta en el modelo el deseo hacia el objeto, lo interpreta como una invitación hacia la imitación, pero, al mismo tiempo, el modelo reacciona rechazando esa imitación, ante el peligro de perder el objeto de su deseo. Este doble imperativo, «imítame» y «no me imites», produce una reacción en cadena cuya resolución será determinante, no sólo en el desarrollo de un individuo, sino también en el de una sociedad ${ }^{12}$.

En un primer momento, cuando sujeto y modelo extienden «la mano» por el mismo objeto, éste pasa a convertirse en un objeto disputado. La confluencia de intereses despierta la rivalidad entre sujeto y modelo. Y la competencia aviva la

9 Cf. GIRARD, R., Mensonge romantique et vérité romanesque, Grasset, Paris 1961, 11-13; en castellano: ID, Mentira romántica y verdad novelesca, Anagrama, Barcelona 1985, 9-11.

10 Cf. Ibid., 17-18 (14).

11 El concepto procede de la psicología norteamericana. Es aplicado a ciertas patologías, en las que se vive un doble imperativo contradictorio: Cf. BATESON, G. y otros, «Hacia una teoría de la esquizofrenia», en ID., Pasos hacia una ecología de la mente, Lohlé, Buenos AiresMéxico, 1976, 231-256.

12 Nos parece interesante citar el ejemplo de la cadena cibernética que Girard utiliza en alguna ocasión para referirse a la situación mimética: «Un segundo punto más interesante todavía, es el papel que desempeña en esta teoría (de la información) el principio del feedback. En vez de ser simplemente lineal, como en el determinismo clásico, es circular. El suceso $a$ desencadena el suceso $b$, que a su vez desencadena otros sucesos, pero el último de ellos vuelve sobre $a$ y reacciona sobre él. La cadena cibernética se cierra sobre sí misma. El feedback es negativo si todos los movimientos se producen en sentido inverso a los movimientos anteriores y, por consiguiente, los corrigen de modo que se mantenga siempre el equilibrio. Pero el feedback es positivo si los movimientos van siempre en el mismo sentido y no dejan de ampliarse; entonces el sistema tiende al runaway o al desbocamiento que desemboca en su ruptura y en su destrucción completa». GIRARD, R., Des Choses cachées depuisla fondation du monde, Grasset, Paris 1978, 317 (330). Las crisis miméticas de las que hablaremos más adelante constituyen una especie runaway. 
ambición en los protagonistas. Cuanto más hace el sujeto por alcanzar el objeto del deseo, más obstáculo pondrá el modelo para evitar que le sea arrebatado lo que ya consideraba como propio, pues su deseo era anterior. El sujeto no comprende la causa de la resistencia que el modelo le ofrece (pues al copiar el deseo del modelo entiende que éste le sugiere hacerlo), por lo que considerará que la falta está en sí mismo. Esta interpretación del sujeto derivará hacia una revalorización tanto del objeto como del modelo. El valor del objeto crece en proporción directa a la resistencia con que tropieza el sujeto en su adquisición. Por consiguiente, el sujeto, ignorante del mecanismo de la rivalidad causada por el deseo, atribuye al objeto más valor de lo que en realidad tiene. Del mismo modo, el valor del modelo crece gracias a la fuerza con que impide la adquisición del objeto.

Para Girard la transfiguración del objeto y del modelo a los ojos del sujeto es lo más característico de este momento de la relación mimética, hasta el punto de considerar que en verdad hay deseo mimético cuando se produce esta transfiguración. Nuestro autor califica esta transformación de «metafísica»:

«Esta transfiguración que no guarda ninguna correspondencia con la realidad hace, sin embargo, que el objeto aparezca transfigurado como lo más real que pueda haber. Se la puede calificar de ontológica o metafísica. Se puede decidir no utilizar la palabra deseo más que a partir del momento en que el mecanismo incomprendido de la rivalidad mimética ha conferido esa dimensión ontológica o metafísica a lo que antes no era más que un apetito o necesidad $»^{13}$.

En este momento, la dinámica del deseo adquiere la estructura de un sistema, en el cual los diferentes elementos del mismo reaccionan unos sobre otros. El prestigio del modelo, la resistencia que éste opone, el valor del objeto, la fuerza que el deseo inspira, todo ello no deja de reforzarse en un dinamismo pernicioso.

El deseo muestra ya su carácter contagioso. A diferencia de la mediación externa en la que no era posible el contagio del deseo, ya que la distancia impedía el contacto entre sujeto y modelo, ahora el carácter contagioso se va haciendo más presente y traerá mayores consecuencias a medida que la dinámica avance y el deseo se haga más intenso.

Las reacciones que sujeto y modelo pueden desencadenar durante este proceso son variadas. Los agentes de la dinámica del deseo pueden completar el ciclo del mismo pasando a siguientes estadios o encontrar otras alternativas, engañosas en la mayoría de los casos, que traten de inclinar la balanza del deseo a su favor. Una u otra posibilidad depende de múltiples circunstancias, pero queremos destacar en particular el factor sociocultural. Tanto la propia experiencia de los individuos, respecto del deseo, como la estructura social y cultural pueden ser determinantes en las diferentes estrategias que el deseo mimético adopte en los individuos ${ }^{14}$.

13 Ibid., 320-321 (334).

14 Este factor sociocultural de la dinámica del deseo es una de las líneas de argumentación de Mentira romántica, verdad novelesca. Allí, Girard trata de demostrar que el deseo no 
La relación entre sujeto y modelo es de lucha, de esfuerzo por conquistar el objeto del deseo. Girard compara esta lucha con la dialéctica del amo y el esclavo $^{15}$. Aquel de los rivales que termine confesando y exhibiendo su deseo ante el otro se convertirá en esclavo, humillando su orgullo. Entonces, la reciprocidad que mantenía la lucha se romperá y, desde ese instante, el amo sentirá verdadero desinterés por el objeto que el rival le mostraba, ya que comprobará la falsedad de la transfiguración que había realizado. En consecuencia, al perder el objeto su valor, el rival perderá también su dignidad con él.

Acabamos de ver al sujeto, que salió triunfante de la dialéctica amo y esclavo, sentirse decepcionado con la posesión de un objeto que había sido transfigurado en su valor. Esta decepción le lleva a buscar nuevos objetos allí donde más resistencia se le ponga. Pues a mayor obstáculo más se revaloriza el objeto y, por tanto, el sujeto creerá, engañado, que aquello que vive como carencia se encuentra ahí. Pero a cada posesión, a cada victoria sobre el rival, el amo se sentirá más desilusionado y hastiado. La lógica de su pensamiento insistirá en una búsqueda que irremediablemente le llevará al fracaso. Cada decepción acumulada le obliga a que la oposición al obstáculo sea más prepotente y la dinámica del proceso se acelerará, hasta dejar de buscar directamente los objetos para centrarse en el mismo obstáculo.

Esta es una de las maneras en que la relación sujeto-modelo puede alcanzar un mayor grado de enfrentamiento y violencia. Es posible también que simplemente la relación se exaspere por la misma dinámica del «double bind», sin que ninguno de los dos agentes del deseo alcance el objeto. En cualquier caso, nos encontraremos en una segunda fase de la mimesis de rivalidad, cuando el modelo pasa a convertirse más en obstáculo que en rival y la atención del sujeto se centrará exclusivamente sobre el modelo, olvidando el objeto hacia el que se dirigía el deseo. En este estadio, la mediación doble, ya no es tal. Más bien nos encontramos en situación de dobles sin mediación, es decir, en la esencia de

se manifiesta de la misma manera en autores que reflejan en sus obras épocas diferentes. Este descubrimiento es fundamental tanto para el análisis antropológico como para el religioso que realizará con posterioridad. Cf. GIRARD, R., Mensonge romantique et vérité romanesque, Grasset, Paris 1961.

15 Cf. Ibid., 114-117 (102-104). Girard califica esta lucha de dialéctica del amo y del esclavo en analogía a la de Hegel, pero nuestro autor cree que entre ambas hay diferencias. Hegel, afirma Girard, confía en la lógica y en la reflexión histórica, como proceso que permite llegar a la reconciliación del Espíritu. Los marxistas creen en esta reconciliación y por eso proclaman el advenimiento de una sociedad sin clases. En el caso del novelista, su confianza, o desconfianza, está puesta en la realidad de las relaciones humanas y por lo que se ve nada nos ayuda a creer que la reconciliación llegará al final, puesto que el futuro de la dialéctica del deseo parece ser la muerte.

Por otra parte, hemos de recordar que el deseo de Hegel es deseo de reconocimiento del otro, mientras que para Girard el deseo es deseo por un objeto según el otro: «De manera que la dinámica de la rivalidad mimética tiene sus raíces en un objeto disputado no en ese "deseo hegeliano de reconocimiento" que yo siempre consideré como un derivado — en la medida en que se asemeja al de Hegel— de interferencias miméticas más elementales tendentes a conseguir un objeto» (R. GIRARD, Literatura, Mimesis y Antropología, Gedisa, Barcelona 1997, 204). 
la relación (si es que se puede hablar de esencias en lo que por definición va a ser proceso e inestabilidad). Girard denomina a este momento «relación de dobles», en la cual lo característico es la reciprocidad de la relación y la pérdida del objeto. El sujeto copia el deseo del modelo, y éste a su vez redobla su deseo, tratando de obstaculizar el deseo del sujeto. Esta reacción del modelo es, en el fondo, un intercambio de papeles con el sujeto, pues el modelo también está copiando el deseo imitado del sujeto. La mutua interacción de esta dinámica es la que provoca la reciprocidad y, por tanto, la falta de diferencias, ya que ambos están imitándose el deseo, copiándose el uno al otro. Así, la reciprocidad es la relación en que el modelo pasa a ser sujeto y el sujeto se convierte en modelo, en una dinámica persistente de intercambio de papeles. Esta relación intensificará las características del estadio anterior, de tal modo que la ambigüedad y transfiguración de significados serán más patentes: cada individuo será para el otro un ser adorable, en tanto que modelo, pero también odioso, ya que será el obstáculo a batir.

Sin darse cuenta, sujeto y modelo transforman la relación en pura simetría. Se encuentran enredados el uno en el otro. Sin embargo, la dinámica sigue avanzando porque ninguno de los dobles está dispuesto a reconocerse igual al otro, cada uno quiere afirmar su singularidad, aspiran a ser diferentes. Por eso se niegan a admitir la reciprocidad, la cual acaba triunfando a pesar de ellos, gracias a las estrategias que cada uno descubre y pone en práctica con la intención de combatirse mejor. Empeñados ambos protagonistas en negar su reciprocidad, interpretan la aparición de esta dinámica de dobles como algo alucinatorio, porque ellos, insertos en la perspectiva del deseo, no ven más que su propia identidad. Pero el resultado final, la verdad de la imitación del deseo, es que éste acaba en una relación de dobles, cuyo final parece conducir a la locura, fruto de la alucinación.

Si consideramos esta relación desde la perspectiva del sujeto, veremos que, desde el instante en que la dinámica mimética comienza, todo apunta a que el sujeto se halle cada vez más convencido de que tanto fracaso en la consecución del objeto es debido a su incapacidad, a su ser erróneo, y no al modo con que busca satisfacer su sed (copiando el deseo del rival). Este convencimiento engañoso hace que el sujeto se desprecie a sí mismo y tienda a buscar no ya el objeto sino el mediador que le ofrezca el obstáculo más insuperable, es decir, aquel que le pueda humillar constantemente. Por eso, el deseo del objeto va a ser sustituido por el deseo de un mediador que sienta por él repugnancia y rechazo.

Cuando el objeto ha dejado de existir, quedan los dobles, el antagonismo puro, sin nada que provoque objetivamente esa separación de ambos. La mimesis es pura reciprocidad o pura violencia, tendiendo a la propagación y división. No se tratará de un sujeto y un modelo, sino de la implicación de otros sujetos. La mimesis invita a la mimesis, como la violencia llama a la violencia. Es el momento del paso de lo interpersonal a lo social, algo que ocurre con más facilidad en determinadas circunstancias culturales. Nos encontramos, así, en el terreno de la crisis mimética, cuando las sustituciones son constantes y el grado de intensidad mimética y la violencia van en aumento. 
¿Qué salida se puede esperar en ese instante de la dinámica?

Del mismo modo que el proceso de la mimesis de apropiación se va haciendo más contagioso y va facilitando la propagación de la violencia en el seno de un grupo, es posible que, a causa del mismo contagio, esa mimesis acabe convergiendo toda la rivalidad sobre un único adversario. El cual se convertiría en la víctima de todos.

Este proceso, que pasa de una mimesis divisiva a una mimesis unitiva, es lo que Girard llama la mimesis de antagonismo. Los sujetos, en el momento máximo de la crisis, se unen inconscientemente en contra de un individuo sobre el que descargan toda la violencia, que hasta ese mismo instante era dispersa e indiferenciadora. Esta transferencia unánime de la violencia sobre un individuo producirá un efecto que acabará con la violencia que aturdía a todos y devolverá la paz al seno del grupo. Este es el denominado efecto del chivo expiatorio.

Pero antes de entrar en su descripción quisiera establecer una conexión con el análisis que René Girard realiza de Nietzsche. El pensador francés cree que a lo largo de la historia, tan sólo algunos personajes excepcionales han sido capaces de descubrir el proceso de la mimesis que caracteriza al ser humano. En concreto cree que esto se ha dado especialmente en el ámbito literario. En su obra Mentira romántica y verdad novelesca, destaca cómo los grandes autores de la literatura reflejan en sus obras este descubrimiento, que en muchos casos tiene que ver con un proceso de liberación espiritual de carácter personal, que ha ido unido al mismo descubrimiento de la dinámica de la mimesis. Para el pensador francés este proceso sorprendentemente también se da en Nietzsche, por eso será tan importante ver cómo se refleja en su vida y qué hace con ese conocimiento.

\subsection{Chivo expiatorio}

Si el análisis de las dinámicas miméticas es correcto y se traslada al proceso de hominización, habría que considerar qué consecuencias tiene en la evolución humana. En ese instante debemos suponer que existe un menor peso de lo instintivo y, por lo tanto, un mayor peligro de que se agraven las situaciones conflictivas, ya que se pierden las estructuras de dominancia. En este caso, la violencia puede instalarse más tiempo en el seno de una comunidad, con los consiguientes peligros de propagación e, incluso, aniquilación. La pregunta que se plantea Girard es cómo se pudo resolver este problema en el paso de lo animal a lo humano. La respuesta para nuestro autor es la resolución mediante el mecanismo del chivo expiatorio, el segundo concepto clave en su pensamiento.

Este término se refiere al mecanismo que se produce en un grupo social durante una escalada mimética que deriva hacia la violencia y cuya resolución es la canalización de esa violencia hacia un individuo del grupo. El mecanismo del chivo expiatorio se sitúa principalmente en el origen de la sociedad, pero no en exclusiva. El proceso se podría describir así: si consideramos un grupo humano (los primeros serían homínidos) en el que la relación entre ellos derivara a una situación conflictiva y violenta, es posible que por alguna circunstancia 
encontraran de manera inconsciente un modo de acabar con la violencia y no terminar aniquilándose unos a otros. En el momento de máxima violencia, en la lucha de todos contra todos, cuando ya nadie se acuerde de qué fue lo que la originó, es probable, que por imitación mimética de esos mismos deseos, se unan todos en torno a un mismo deseo: culpabilizar a un individuo y centrar sobre él toda la violencia que estaba dispersa en el seno del grupo. Si llega a producirse tal hecho, asesinarán a esta víctima y en el mismo momento en que acaben con ella, acabarán con la pesadilla que amenazaba a toda la comunidad.

El fin de la violencia, resultado de esta muerte, les impresionará de tal modo que todos los supervivientes quedarán convencidos de que la causa de todos los males era la víctima, pues al acabar con ella ha vuelto la paz. Pero, también, considerarán que la causa de la paz será la víctima, pues con su muerte ha renacido la paz. Es esta convicción, y el modo como afecta a la comunidad, lo que hace que esa víctima se convierta en referente máximo de todo lo nuevo que aparece en la comunidad. Hasta el punto, que esa referencia hace coincidir en la víctima las características de lo sagrado ${ }^{16}$.

Así, si la comunidad no quiere recaer en la violencia, entenderá que debe evitar todo aquello que le llevó antes a ella. Y si, por alguna razón, están en peligro de que vuelva a ocurrir, tratarán de imitar el mismo proceso que les llevó a la paz. Este doble modo de acción es lo que en religión se llaman prohibiciones y ritos ${ }^{17}$.

Además de este supuesto origen histórico de lo religioso, el mecanismo se constituye, podríamos decir, en el punto cero de la historia humana. El surgimiento de la humanidad a partir de una crisis violenta y radical se convierte en factor estructural del hombre, porque desde él surgen todos los elementos necesarios para la aparición de la cultura, que lo conforma.

$\mathrm{Al}$ situar el mecanismo expiatorio en el origen humano, Girard identifica el proceso social con la aparición cultural: identifica la crisis social con la indiferenciación; por el contrario, la resolución de la crisis es vivida como estructuración. Lo sagrado no sólo es sagrado, es el primer significante diferencial. Y a partir de él se establecen todas las distinciones necesarias para la elaboración simbólica, pues lo sagrado es el principio máximo que distingue lo que es bueno de lo que es malo, lo que es dentro de lo que es fuera, etc. El criterio desde el que se realiza cualquier diferenciación es la relación o no con la violencia. Todo lo que sea la violencia o recuerde la violencia corresponde a lo sagrado y está en función de él. A partir de la religión, surge todo lo que llamamos cultura.

16 Este proceso se realiza de manera inconsciente, estamos en la etapa de hominización y no podríamos considerar la posibilidad de un pensamiento elaborado. Más bien habría que considerar que la relación que se establece entre víctima y violencia o paz, se realiza por asimilación o cercanía.

17 Las prohibiciones tienen el papel de alejar la violencia de la comunidad lo máximo posible para que no vuelva a ocurrir lo mismo que favoreció la crisis violenta. Del mismo modo, los ritos ejercen el rol de canalizar la violencia, tratando de repetir de manera análoga el mecanismo del chivo expiatorio. Por eso las religiones son en origen sacrificiales. 
Mediante la relación que se establece con lo sagrado se crea un saber que permite diferenciar, sustituir e identificar, es decir, recrear todo lo necesario para estimular el desarrollo de la conciencia humana y, consecuentemente, la cultura. En consecuencia, según Girard, la cultura, que conforma y determina al hombre, es heredera de todo lo sacrificial.

A partir de lo dicho, resulta evidente que para Girard la religión es la única posibilidad para la emergencia del hombre en el proceso de hominización. Es la condición necesaria para la superación de la violencia. Sólo con esta hipótesis sobre el origen de la religión el pensamiento de R. Girard tiene valor en sí mismo. Pero, si la obra del francés nos resulta poderosa, es porque lleva el mecanismo expiatorio más allá y lo transforma en un sistema desde el que se deduce toda una concepción del ser humano.

A decir verdad, más bien deberíamos señalar que el papel estructural concedido por Girard al mecanismo expiatorio conforma una especie de dialéctica, según la cual el carácter mimético del ser humano propicia la emergencia del mecanismo, con todas sus implicaciones, y éste, a su vez, propicia la emergencia del ser humano y su desarrollo evolutivo. Pero, existe un elemento que no es tan positivo: la humanidad se ha constituido sobre la misma violencia; y la condición de posibilidad de su misma existencia es que controle el peligro de la violencia que siempre le amenaza. Podríamos decir que toda la cultura, según Girard, está al servicio de la contención de la violencia, de una manera más o menos explícita. Por otra parte, el pensador francés cree que la misma cultura se va recreando de tal manera que en la medida en que la humanidad evoluciona, se va a producir un proceso de secularización de las instituciones, que alejan la intrínseca relación que mantenían con la violencia y el servicio que hacían para contenerla. Sin embargo, insistimos en que estructuralmente toda la cultura y todas las instituciones están ancladas en ese mecanismo sacrificial, que es útil para toda la humanidad, en tanto que le aleja de la violencia o la canaliza, pero es un lastre en tanto que responde a un mecanismo inconsciente fundado sobre una falsedad básica: que la violencia procede de otro. Será necesario desvelar el mecanismo para que el hombre pueda llegar a hacerse consciente de este engaño.

\subsection{Religión}

He descrito el mecanismo social y antropológico mediante el cual Girard concibe el origen de la religión. Sin embargo, para comprender el conjunto del pensamiento girardiano hemos de abordar un tercer elemento, su teoría sobre la religión y el concepto que sostiene a ésta, y para ello nos hemos de remontar a las primeras obras del autor. El análisis de la mimesis en la literatura demostraba que existía una analogía intrínseca entre la relación establecida entre sujeto y modelo de la relación mimética y la relación religiosa. Girard cree que la relación mimética puede llevar al sujeto a convertir el modelo en una especie de ídolo transfigurado que vendría a ejercer el papel de un pequeño dios. Este ídolo falso conducía al sujeto hacia una existencia de esclavitud. Ejemplos de 
esta existencia los muestra Girard en su análisis de los personajes de la literatura de Dostoyevski. Y algo análogo encontraremos en Nietzsche.

Esta concepción permitió a Girard deducir que en el ser humano hay una tendencia natural hacia lo absoluto, que encuentra su respuesta en lo que llamamos religión. Una relación que se caracteriza por darse unidas la experiencia de la trascendencia y el deseo de ser «absoluto». No obstante, el peligro es que el hombre puede confundir ese ser absoluto con otros seres que no son absolutos en realidad, sino que son proyecciones falsas del mismo, lo que llamamos ídolos.

En este presupuesto inicial debemos ver el punto de partida de toda la hipótesis. Girard intenta formular una explicación de la religión que combine estos elementos: la aspiración hacia la trascendencia, la presencia de lo absoluto y la adaptación al carácter mimético del ser humano.

La hipótesis del mecanismo del chivo expiatorio ha convertido a la religión en el factor imprescindible para la supervivencia humana, para superar el mismo conflicto. Basándose en un análisis, principalmente sociológico, nuestro autor deconstruye las religiones históricas, sus ritos, sus mitos y sus derivaciones culturales, de tal manera que hace plausible su hipótesis sobre la estrecha relación entre violencia original y aparición de las religiones.

Ahora bien, este análisis conduce a una concepción religiosa que contiene todos aquellos elementos que la filosofía, en especial el ateísmo de la sospecha, ha criticado a la religión. Por eso, la pregunta que surge es cómo se llega a esa redención, que Girard busca, si la religión que nace en el origen de la historia encarcela al hombre en estructuras externas para evitar la expansión de la violencia. Recordemos que, desde el esquema de la mimesis, lo sagrado sacrificial sirve de modelo para la realización del hombre en sociedad, pues evita la caída en la dinámica de la violencia. Pero, como acabamos de advertir, lo hace a costa de una parcialización del potencial del ser humano.

¿Cómo puede, pues, liberarse el hombre de esa dinámica sacrificial que lo estructura?

El argumento girardiano señala que mientras que todas las religiones son sacrificiales según el mecanismo del chivo expiatorio, en la religión judía se produce un hecho singular que la diferencia de todas las demás. Desde su inicio hay una dinámica emergente, que desembocará y culminará en Jesús; una dinámica que va desvelando la verdad de los mecanismos sacrificiales y va destruyendo el engaño sobre el que se habían construido todas las religiones. Esta dinámica o revelación es el reconocimiento de la inocencia de la víctima ${ }^{18}$.

Girard se centra en el análisis de los textos bíblicos. En el Antiguo Testamento, nos muestra que la comprensión religiosa y la relación del hombre con Dios mantienen el mismo esquema sacrificial que las religiones primitivas. Pero a

18 En los últimos años René Girard ha matizado esta idea y ha ido mostrando que en otras religiones el proceso de revelación también se ha dado, aunque sigue afirmando que nunca con la misma claridad y plenitud que en el cristianismo. Cf. GIRARD, R., El sacrificio, Encuentro, Madrid 2011. En esta obra, por ejemplo, analiza los textos de la religión hindú. 
diferencia de éstas, se produce un proceso de reconocimiento de la inocencia de las víctimas. Un reconocimiento que no se había dado en ninguna otra cultura o religión histórica. Con todo, esta revelación no es plena, pues en el judaísmo veterotestamentario permanece un cierto sacrificialismo tanto en las dinámicas relacionales humanas, como en la misma concepción de Dios.

Además, para que este sacrificialismo sea superado, no puede bastar con una crítica externa al mismo, es necesario vencerlo mediante una respuesta equivalente al mecanismo que lo produjo. Por ello, para que la revelación llegue a su plenitud es necesaria la vida y muerte de Jesús, entendida como repetición reveladora y desactivadora de este mecanismo expiatorio. Girard se esfuerza en demostrar que en los evangelios se reconoce la continuidad entre la revelación que se efectúa en ellos y las religión anterior; que en Jesús se produce un rechazo pleno de la violencia, que Dios no tiene nada que ver con la violencia de los hombres; y que la muerte de Jesús, pese a ser análoga a las muertes anteriores de las víctimas expiatorias de todas las religiones, es estructuralmente diferente, pues en vez de confirmar el mecanismo del chivo expiatorio, lo revela. La clave de esta transformación ejercida por Jesús es hacer consciente lo inconsciente, mostrando la falsedad de una estructura religiosa eficaz pero esclavizante ${ }^{19}$.

Otra cuestión es el proceso de desactivación de ese mecanismo ejercido por el cristianismo. El mismo pensador francés considera que en la historia los cristianos han actuado con frecuencia contra su misma religión haciendo una lectura violenta de la misma. Pese a ello, nada ha podido impedir la fuerza de la revelación y la desactivación del mecanismo porque es independiente de la misma actuación de los cristianos. Y en la historia, poco a poco, esta revelación ha ido ejerciendo su efecto antiviolento. A veces ha sido la misma dinámica de la historia la que ha ido produciendo una desactivación del mecanismo y otras han sido personajes revelantes, como F. Nietzsche, quienes han intuido el papel revelatorio del cristianismo.

Es en este contexto en el que tenemos que leer el análisis que R. Girard realiza de Nietzsche. En nuestra opinión, una lectura en clave expiatoria del pensamiento del filósofo alemán descubre la lógica de la misma evolución de su pensamiento. A partir de la comprensión expiatoria de la cultura, parece lógico

19 Acerca del término «sacrificio», en la obra de Girard se ha producido una evolución. En El misterio de nuestro mundo (Cf. Cap. 7 y 8), René Girard insistió sobre el carácter no sacrificial del cristianismo. Lo hacía con el deseo de mostrar la diferencia con respecto a otras religiones. Sin embargo, años después se abrió a considerar el término "sacrificio», aplicado al cristianismo, sólo que entendido no en clave sustitutoria, como la del mecanismo expiatorio, sino en clave de entrega y donación de sí. La primera vez que muestra este cambio es en Cuando empiecen estas cosas a suceder...; más adelante, en otras obras, ofrecerá una explicación más clara sobre este cambio. Cf. GIRARD, R., Quand ces choses commenceront... Entretiens avec Michel Treguer, Arléa, Paris 1994, 169-170; en castellano, ID, Cuando empiecen estas cosas a suceder... Conversaciones con Michel Treguer, Encuentro, Madrid 1996, 134135. ID, Celui par qui le scandale arrive, Desclée de Brouwer, Paris 2001, 72-82; en castellano: ID, Aquel por el que llega el escándalo, Caparrós Eds., Madrid 2006, 55-60. 
que el pensamiento de F. Nietzsche acabe en el nihilismo. La obra del pensador germano sería el resultado de la doble confluencia de la máxima revelación y del rechazo de la misma. F. Nietzsche es la máxima revelación porque ha comprendido el verdadero significado revelatorio del cristianismo, y, sin embargo, rechaza este cristianismo. Y la elimina para convertirse él mismo, cualquier superhombre, en su sustituto, es decir, para negar la posibilidad misma de una trascendencia. Y en eso consiste el nihilismo: en el rechazo de la posibilidad misma de cualquier valor, de cualquier referente que diga al hombre cómo debe actuar. Nietzsche es la violencia esencial y opta por ella. Su filosofía conduce al hombre hacia una situación máxima de violencia. Por eso elige entre Dionisos o el crucificado, o lo que es lo mismo, entre él como dios o el cristianismo. Veamos esto en los siguientes apartados.

\section{NietZsche, El HOMBRE Y SU PENSAMiENTO}

E. Colomer ${ }^{20}$, citando a K. Jaspers, observa que si deseamos comprender el pensamiento de Nietzsche será necesario previamente entrar en contacto con su vida. Este presupuesto, que tantos estudiosos de Nietzsche han considerado, es también mantenido por Girard. Así, partiendo de las diferentes perspectivas que nuestro autor presenta del filósofo alemán, podremos comprender en una unidad las virtudes y las carencias que el pensamiento nietzscheano tiene a la luz de la lectura antropológica girardiana. En este apartado consideraremos la perspectiva biográfica, a partir de una lectura mimética de la vida de Nietzsche. Aspectos que, como veremos al final de nuestro análisis, parecen ser determinantes en la expresión de su posición, en particular sobre la religión.

Para comprender el lugar desde el que comienza el análisis de Girard, comenzaremos por unas breves reseñas biográficas de Nietzsche ${ }^{21}$. Éstas nos recuerdan que el filósofo vivió y creció en un ambiente familiar dominado por el elemento femenino y la rigidez religiosa. Sus primeros intereses intelectuales se centran más en los estudios filológicos que en los teológicos, hacia los que en principio el joven Nietzsche estaba dirigido. Sin embargo, pronto esta atracción se desplazaría hacia la filosofía, gracias al contacto con la obra de Schopenhauer. Esta inclinación se ve enriquecida y fortalecida cuando poco tiempo después, hacia finales de 1868, conoce al matrimonio Wagner, hecho fundamental en su vida y obra. Pero años más tarde rompe con los Wagner alejándose de los ideales que su amistad suscitaban. Esta ruptura coincide también con la aparición de los primeros síntomas de su enfermedad. Huyendo del desencanto por la ruptura, Nietzsche decide viajar por Europa, aunque

20 Cf. Colomer, E., op.cit., 227. Cf. JASPERs, K., Nietzsche. Einführung in das Verständnis seines Philosophierens, Walter de Gruyter, Berlin 1950, 20.

21 Cf. Carbonell, M., «Presentación», en Nietzsche, F., Així parlà Zaratustra Edicions 62, Barcelona 1983, 7-10. 
continúa escribiendo bajo estados tanto de creciente entusiasmo como de hundimiento. La fragilidad psicológica se va acentuando a medida que los acontecimientos en su vida se van precipitando (fracaso amoroso, muerte de Wagner, dificultades con su hermana) hasta que en 1889 se produce el hundimiento de su razón y entra en la demencia. El resto de sus días, hasta 1900, los pasa con su familia, mientras la grave enfermedad progresa lentamente.

Para Girard ${ }^{22}$, la demencia de Nietzsche es susceptible de una lectura en clave mimética. Para ello parte de las relaciones que el filósofo mantuvo durante su vida con Richard Wagner y su esposa, Cósima. Esta amistad, de intensa emoción y consolación en sus mejores momentos, se transformó para Nietzsche, sin aparente explicación, en una herida abierta en su sensibilidad, que nunca llegó a cicatrizar y que, de una manera u otra, se refleja en su pensamiento.

El proceso de la relación presenta las características del dinamismo mimético: Wagner, modelo explícito para el deseo de Nietzsche, ídolo al que se le rinde público respeto y admiración, se convierte, años más tarde, en rival, en obstáculo que al mismo tiempo es admirado y odiado. Nietzsche mismo describe en sus obras las fases de esta relación.

En El nacimiento de la tragedia con su Prólogo a Richard Wagner muestra esa admiración idolátrica hacia el músico. En esta obra, nacida a partir de la amistad y el diálogo entre ambos, esboza una concepción de la vida griega partiendo de la filosofía de Schopenhauer y del ideal estético de Wagner. La admiración no es solamente intelectual: «Richard Wagner, que, como hombre, es de igual grandeza y singularidad que como artista... $»^{23}$. Hay auténtica amistad, que se manifiesta en todos los ámbitos de la persona y que se expresa en Nietzsche en una etapa de máxima felicidad. Hasta el punto de considerar tiempo después que no ha valido la pena alcanzar la superioridad intelectual:

«Yo por mi parte, sufro horriblemente cuando me veo privado de simpatías; y nada puede compensarme haber perdido, por ejemplo, las simpatías de Wagner estos últimos años. ¡Cuántas veces no sueño con él, y siempre rodeado de la atmósfera de nuestra antigua unión! Nunca pronunciamos una mala palabra entre nosotros, ni aún en sueños, y sí en cambio, muchas que fueron alentadoras y serenas, y con nadie he reído tanto como con él. Pero todo ha pasado - iy de qué sirve tener razón contra él en algunos aspectos! ¡Como si eso pudiera borrar de mi memoria aquella simpatía perdida! $»^{24}$.

La segunda fase de su relación con Wagner se expresa años más tarde en sus obras El caso Wagner y Nietzsche contra Wagner. Y por supuesto en Ecce Homo. En estos escritos Nietzsche reniega de todo lo escrito antes sobre el músico y muestra su profunda extrañeza y decepción a causa del camino que ha tomado

22 Cf. GIRARD, R., «Superman in the Underground: Strategies of Madness - Nietzsche, Wagner and Dostoyevski»: Modern Language Notes 91 (1976) 1161-1185, (74-94).

23 Nietzsche, F., Epistolario inédito, Biblioteca Nueva, Madrid 1932, 66: Carta a su madre del 16 de junio de 1869.

24 In, Correspondencia, Labor, Barcelona 1974, 83-84: Carta a Peter Gast, fechada en Marienband, 20 de agosto de 1880. 
el arte del alemán. Este cambio, explicable bajo razonamientos teóricos, no deja de tener factores relacionales que el mismo filósofo los califica de enfermizos: «El acontecimiento más grande de mi vida fue una curación. Wagner forma parte simplemente de mis enfermedades ${ }^{25}$. Nietzsche ha admirado tanto a Wagner, que pese a momentos de debilidad ante el recuerdo por el amigo perdido, lo que realmente surge es la separación:

«Lo que en aquel momento se decidió no fue mi ruptura con Wagner; yo adquirí conciencia de una aberración general de mis instintos, cuyo error principal ya se llamase Wagner o el cargo de profesor de Basilea, era solamente un indicio. Se apoderó de mí la impaciencia "de mí mismo"; comprendí que era tiempo de meditar sobre mí mismo... Entonces fue cuando adiviné también por primera vez la correlación que existe entre esta actividad escogida contrariamente al instinto natural, entre lo que se llama "vocación", cuando nada os llama a ella, y esa necesidad de llenar el sentimiento de vacío y de inanición del corazón con ayuda de un arte que sirve de narcótico; del arte wagneriano, por ejemplo.... ${ }^{26}$.

Las palabras de Nietzsche parecen anunciar que tal separación es la solución que ha encontrado a su situación mimética. Él cree liberarse de la esclavitud de su relación con Wagner. Pero, en realidad, no habrá liberación, aunque utilice estos términos. ¿Qué libertad puede ser conquistada desde la reacción? No, no es posible alcanzar esa libertad. Nietzsche se había dado un Dios, Wagner. Y consciente de la esclavitud que sufre, necesita afirmarse a sí mismo frente al Dios, por eso se postulará a sí mismo como Dios. Para confirmar esta afirmación no hay más que observar el subtítulo y los capítulos de Ecce Homo. El libro lo titula, «Ecce Homo o cómo llegar a ser lo que se es», y en él hay apartados como Por qué soy tan sabio, Por qué soy tan inteligente, Por qué escribo tan buenos libros o Por qué soy un destino. No podemos negar que Nietzsche confía en su endiosamiento. Pero el sentimiento naciente producido por la reacción a esa amistad fallida sólo tiene un nombre y se llama resentimiento. Para Girard ${ }^{27}$, el resentimiento sólo se puede entender desde la perspectiva de este deseo mimético. Pues, el resentimiento es el renacer del deseo que choca con el obstáculo del modelo.

Muchos especialistas de Nietzsche, admitiendo la importancia de esta relación, creen que lo que en ella se pone en juego es tan sólo una determinada interpretación filosófica o estética de la vida, defendida por Nietzsche y de la que Wagner parece haberse alejado ${ }^{28}$. Es frecuente cuando analizamos el

25 ID, Nietzsche contra Wagner, Obras Completas, Tomo X, Aguilar, Madrid 1932, 152.

26 ID, Ecce Homo, OC, X, 272-273.

27 Cf. GIRARD, R., «Système du délire. (Review of "L'anti-Oedipe", by Gilles Deleuze)»: Critique 28, 306 (1972) 957-996. Reeditado en ID, Critique dans un souterrain, Le livre de Poche, 1993, 199-250 y en castellano en: Literatura, Mimesis y antropología, 95-128. La referencia, en LMA, 102. A partir de ahora para éste artículo tan sólo citaré la versión en castellano.

28 Cf. Valverde, J. M., Nietzsche de filólogo a Anticristo, Planeta, Barcelona, 1993. Especialmente cap. 3 y 10; también: ChaIX-Ruy, J., Sintesis del pensamiento de Nietzsche, Nova Terra, Barcelona, 1974, cap. 2. 
pensamiento de algún filósofo que lo aislemos de los elementos afectivos, que lo pueden condicionar, o minusvaloremos estos factores, cuando en muchos casos son inseparables ambos aspectos. Sin embargo, para Girard, la variabilidad de esta relación describe algo más fundamental, como es una experiencia interna que se reflejará tanto en su pensamiento como en su demencia. En la relación aparecen el sujeto y el modelo, característicos de la mimesis. Girard cree que en ella es observable cómo se desplaza el papel del objeto (la gloria, el triunfo intelectual o, incluso, Cósima, la mujer de Wagner) para manifestarse la mimesis de rivalidad en la que tanto sujeto como modelo tratan de ser el modelo del otro. En ese instante el deseo por el objeto es canalizado hacia el ser del modelo, lo que Girard llama deseo metafísico. Este deseo atribuye al modelo un plus de ser que lo convierte en el Dios al que adorar, la trascendencia desviada. Pero los obstáculos que el modelo pone al sujeto conducen la relación hacia la ambivalencia de sentimientos característica de tal deseo. Así ocurre con el éxito de Wagner, como héroe cultural del pueblo alemán. Tal éxito es vivido por Nietzsche como el obstáculo que le impide alcanzar la meta que se ha propuesto a través de la mediación de su héroe. Esa situación despierta en el filósofo los sentimientos de rechazo hacia el modelo dado. Y por tanto, surge el resentimiento.

Desde aquí podemos acudir a las reflexiones filosóficas, porque este sentimiento es el mismo que Nietzsche atribuye a los débiles creyentes, que movidos por una moral «pacata» impiden a los grandes hombres realizarse. El filósofo prusiano no parece ser consciente de su proyección en aquello que rechaza o, quizá, por eso mismo lo rechaza. Al menos así se puede deducir de las palabras de Girard: «Las víctimas del deseo metafísico adoptan siempre sus ideas políticas, filosóficas y religiosas en función del odio. Para las conciencias enfrentadas el pensamiento es sólo un arma» ${ }^{29}$.

Por consiguiente, tanto la idea de voluntad de poder, como el concepto de «superhombre» o la crítica al cristianismo deben reflexionarse desde la situación relacional de Nietzsche. Él, tras haber convertido a Wagner en su trascendencia desviada, dedicará todos sus esfuerzos a recuperar su identidad perdida en el modelo. Afirma René Girard:

«El paciente retorna, no a su infancia, sino a su primera relación con el mediador, cuando el modelo no habiéndose convertido todavía en obstáculo era abiertamente objeto de culto. Por obra de lo que ahora se le representa como una trampa diabólica, la víctima se da cuenta de que ella misma consintió y fomentó el injusto triunfo del mediador. Ahora se ve desposeída de su propio yo y trata cada vez más desesperadamente de llenar el vacío no sólo con el engañoso Richard Wagner sino con cuanto modelo histórico o mitológico impresione su fantasía» ${ }^{30}$.

29 GIRARD, R., Mensonge romantique et vérité romanesque, Grasset, Paris 1961, 164 (144).

30 ID, «Estrategias de locura: Nietzsche, Wagner, Dostoievsky», en: ID, Literatura, Mimesis y Antropología, Gedisa, Barcelona 1997, 76. 
Según la dinámica mimética, la negación de Dios suprime la trascendencia absoluta y externa al mundo. Sin embargo, esta supresión no nos deja en el vacío, nos acaba conduciendo a buscar un sustituto de esa trascendencia en el más acá. En el caso de Nietzsche esta desviación no se conforma con buscar dioses en los otros, aquí la desviación será mayor. El nuevo Dios será el propio yo $^{31}$ : el hombre de la voluntad de poder que aspira a llegar a ser el superhombre. Sin embargo, todo este proceso no se realiza desde el desconocimiento de las relaciones humanas, sino desde la conciencia de su dinámica. El genio de Nietzsche y su capacidad de interiorización sobre sí mismo le ha llevado a comprender la dinámica de la psicología humana. Esto precisamente es, para Girard, lo que convierte a Nietzsche en un filósofo particularmente atractivo. Nietzsche es el equivalente filosófico de Dostoyevski, ambos han entendido hasta dónde puede llegar el orgullo humano y las posibles consecuencias de éste. Sin embargo, a diferencia de Dostoyevski, Nietzsche optará por llevarlo hasta sus últimas consecuencias, aunque conlleve sufrimiento o violencia. La prueba de que Nietzsche ha intuido la dinámica del deseo es que los dos conceptos equivalentes al deseo, voluntad de poder y resentimiento, los caracteriza por primera vez separados de los objetos, es decir, media$\operatorname{dos}^{32}$. Lo cual significa que se pueden reducir a la mimesis, en la que el objeto se pierde tras el modelo. En el caso del resentimiento, que entiende Girard como un deseo mediado por el modelo, la solución es la negación de la mediación. Por el contrario, en la voluntad de poder la salida es la ostentación de la mediación: cuando no hay objeto directo al que dirigirse, el deseo acaba por inventar falsos objetos, es decir, se acaba enquistando en la relación con los otros; la ostentación explícita de esta relación enquistada es la voluntad de poder, que se mantiene en la ilusión de dominio.

«El poderío se revela en la rivalidad con otros, esta vez en una competencia voluntariamente emprendida. $\mathrm{O}$ bien la voluntad de poder equivale a nada o bien ella elige objetos en función del deseo del rival para arrebatarlos. En otras palabras, la voluntad de poder y el resentimiento tienen una y la misma definición. Ambos están reducidos a mimesis deseante. Un concepto tal como la voluntad de poder sólo puede salir a la superficie en el momento en el que el deseo, no siendo ya capaz de ocultar su naturaleza mimética, la proclama abiertamente a fin de perpetuar su ilusión de dominio. Por fin el deseo termina por precipitarse temerariamente a los desastres que lo aguardan ${ }^{33}$.

31 Cf. GIRARD, R., Mensonge romantique et vérité romanesque, Grasset, Paris 1961, 273274 (246).

32 La tesis de Girard de la excepcionalidad del pensamiento de Nietzsche tiene en este dato una confirmación: A diferencia de toda la modernidad, F. Nietzsche descubre que el deseo no es espontáneo en el sujeto, sino que viene mediado por otro. Quizás esto explique que el pensamiento del germano esté más allá de la modernidad y plantee una vuelta a los orígenes.

33 GIRARD, R., «Système», 102-103. 
El hombre atrapado por la mimesis de rivalidad, debería reconocer su situación y aceptar el propio resentimiento, algo de lo que fue capaz Dostoyevski ${ }^{34}$, pero que Nietzsche se negó a admitir. El filósofo fue víctima de su deseo. Y así lo veremos en el siguiente apartado.

\section{NiETZSCHE Y LA RELIGIÓN}

En uno de los principales artículos de Girard acerca de Nietzsche, Dionysus versus the Crucified ${ }^{35}$, nuestro autor comienza señalando el silencio del que se ha rodeado la reflexión religiosa en la obra de Nietzsche ${ }^{36}$. Cuestión que Girard considera imprescindible si queremos entender el pensamiento del prusiano. Sobre todo si consideramos que la cuestión religiosa surge más obsesivamente en el instante en que se agudiza su demencia. El argumento, que planea en el análisis del pensador francés, es el siguiente: cuando una persona experimenta existencialmente la dinámica de las relaciones humanas en su complejidad y sin los acostumbrados obstáculos que la sociedad tradicional nos ha impuesto $^{37}$, está en las mejores condiciones existenciales para captar las implicaciones religiosas a las que conduce la antropología de la religión que postula Girard. Si además de la experiencia existencial se es un genio, intelectualmente hablando, como ocurre con Nietzsche, las posibilidades de tal comprensión deberían ser aún mayores. Supuesto esto, la pregunta, que Girard trata de confirmar, es si en la obra de Nietzsche aparecen esas cuestiones que ponen al descubierto toda la hipótesis victimaria y si tienen el mismo sentido que ésta atribuye. La respuesta es afirmativa y eso es lo que trataremos de ver.

Durante la eclosión de las ciencias religiosas en el siglo XIX, una de las líneas de investigación más desarrollada fue la que creyó encontrar suficientes datos como para establecer comparaciones entre las distintas religiones. El término que servía de comparación era la presencia de un drama colectivo en casi todas

34 Cf. In, Dostoïevsky: Du Double à l'unité, Plon, Paris 1963. 119-169. Reeditado en : Critique dans un souterrain, L'Age d'homme, Laussane 1976.

35 ID, «Dionysus versus the Crucified»: Modern Language Notes, 99 (1984) 816-835. Reeditado en The Girard Reader, 244-261. En castellano ha sido publicado (traducción de Ángel Barahona) en Religión y Cultura XLV (1999) 13-34. Las citas se referirán a las páginas de la edición de TGR y entre paréntesis a la traducción castellana.

36 Girard parece olvidar o desconocer obras que han tratado esta cuestión como la famosa de JASPers, K., Nietzsche y el Cristianismo, Deucalión, Buenos Aires 1955; la de Welte, B., El ateísmo de Nietzsche y el cristianismo, Taurus, Madrid, 1962; y en el ámbito francés, del que Girard procede, las obras de Valadier, P., Jésus-Christ ou Dionysos: la foi chrétienne en confrontation avec Nietzsche, Desclée, Paris 1979; o Nietzsche y la crítica del cristianismo, Cristiandad, Madrid, 1982.

37 En la hipótesis de Girard las prohibiciones heredadas de las religiones primitivas ejercen menos presión en la sociedad moderna, más secularizada, que en el pasado. Por tanto, en la época de Nietzsche la dinámica mimética tiene las correcciones características. Cf. GIRARD, R., Mensonge romantique et vérité romanesque, Grasset, Paris 1961, cap. V, VII y VIII. 
las religiones ${ }^{38}$. Se constataba que tanto el cristianismo como las religiones primitivas fundamentaban sus cultos y su mitología en torno a homicidios de personajes divinos. Esta similitud de hechos hizo suponer que todas las religiones eran iguales y procedían de un mismo origen. En el seno del cristianismo esta explicación fue rechazada y se insistía en la singularidad de esta religión, destacando todo aquello que pudiera diferenciarles de las demás religiones y que permitiera presentarse como la única religión verdadera. Esta actitud apologética, que se remontaba ya a los inicios del cristianismo, se basaba en el temor a la pérdida de veracidad y absolutez que siempre había mantenido la religión cristiana. Admitir la posibilidad de la comparación con otras religiones hubiera supuesto poner en duda su origen divino y el carácter universal con el que se presentaba.

Frente a la opinión de su época, el genio de Nietzsche surgió descubriendo, contra la opinión mayoritaria, la singularidad de lo religioso bíblico frente a la religiosidad pagana.

"A diferencia de Heidegger, a diferencia de la mayoría de sus contemporáneos y de nosotros, Nietzsche cree claramente en la especificidad única de la perspectiva bíblica y cristiana. Sus razones no pueden desecharse tan sumariamente como lo serían si fuera cristiano. La falacia etnocentrista no lo haría.

La singularidad de la Biblia y del Nuevo Testamento es afirmada por Nietzsche en un contexto directamente opuesto a la apologética cristiana. Nietzsche intenta asentar su crítica al cristianismo sobre una base menos firme que aquella que fue ya estandarizada en su tiempo, la gran equivalencia positivista de todas las tradiciones religiosas. Él sabía demasiado acerca de la mitología pagana como para no indignarse por la trivial asimilación de lo judeocristiano con lo pagano ${ }^{39}$.

El argumento nietzscheano se fundamenta en la distinción entre la tradición religiosa griega, en especial la dionisiaca, y el cristianismo. El texto clave, calificado por Girard como «el más grande texto teológico del siglo XIX $»^{40}$, que formula la singularidad del cristianismo, aparece en La Voluntad de Poder, es el aforismo número 1052, a partir del segundo parágrafo:

«Los dos tipos: Dionisos y el Crucificado.-

“Dionisos contra el 'Crucificado': aquí tenéis la oposición. No es ésta una diferencia de martirio: el martirio tiene otro sentido. La vida misma, su eterna fecundidad y su retorno determinan el tormento, la destrucción, la voluntad de destrucción. En otro caso, el sufrimiento, el 'Crucificado inocente', es como una objeción contra esta vida, como fórmula de su condenación.

38 Cf. GIRARD, R., Je vois Satan tomber comme l'eclair, Grasset, Paris 1997, 10-13 (9-13).

39 ID, «Dionysus...», 246 (16). En algún momento Girard califica al teólogo Nietzsche como uno de los grandes teólogos desde San Pablo.

40 ID, Quand ces choses commenceront... Entretiens avec Michel Treguer, Arléa, Paris 1994, 198 (156). 
Se adivina: el problema es el del significado del sufrimiento: un sentido cristiano o un sentido trágico. En el primer caso, el sufrimiento es la vía que conduce a una santa existencia; en el segundo, la existencia es considerada lo bastante sagrada para justificar un enorme sufrimiento. El hombre trágico aprueba también el sufrimiento más áspero: para hacer esto es bastante fuerte, bastante completo, bastante divinizador; el cristiano dice que 'no' aun a la más feliz suerte que haya sobre la tierra, y es débil, pobre, lo bastante desheredado para sufrir de la vida en todas sus formas. El Dios en la cruz es una maldición lanzada sobre la vida, una indicación para librarse de ella; Dionisos despedazado es una promesa de vida; ésta renacerá eternamente y volverá de la destrucción » ${ }^{41}$.

Nietzsche compara dos dioses y, con ellos, dos religiones. Las dos tienen en su origen el relato de un homicidio colectivo, un martirio. En el cristianismo tenemos la Pasión y en la religión griega tenemos el asesinato colectivo de Dionisos por parte de los Titanes ${ }^{42}$. Sin embargo, la visión que mantienen ante la violencia homicida es diferente. En el caso de Jesús se insiste en su inocencia y, por tanto, en la culpabilidad de los asesinos. Mientras que con Dionisos, pese a las diferentes versiones que hay del mito, el dios se presenta ambiguo en su significado, unas veces como instigador y otras como víctima, pero en ningún caso se plantea un rechazo de la violencia en el sentido cristiano.

Nietzsche parece comprender la importancia de esta diferencia y la resalta: "No es esta una diferencia de martirio. El martirio tiene otro sentido». Cada religión mantiene distintas actitudes vitales: las religiones paganas están más allá del bien y del mal, asumen lo mejor y lo peor, y afirman la vida en lo que tiene de fuerza, creación y poder; en cambio, la religión cristiana es, para Nietzsche, el rechazo del sufrimiento y una objeción a todo lo que supone «vida». Es la famosa distinción, que ha cuajado en el acervo popular del pensamiento occidental, entre la moral de amos y la moral de los esclavos.

Por tanto, la especificidad bíblica, que interesa a nuestro autor y que supo ver Nietzsche ${ }^{43}$, está en señalar que el cristianismo se presenta como una religión que defiende a las víctimas frente a sus verdugos, que el Dios de los

${ }^{41}$ Nietzsche, F., La Voluntad de poder, Libro IV, II, 1052, en: OC, IX, 191. Las comillas son del propio Nietzsche.

42 En Girard, R., Le bouc émissaire, Grasset, Paris 1982, 108. En castellano: Id, El chivo expiatorio, Anagrama Barcelona 1986, 98. El mismo Girard describe este mito, tomado de Eliade: «Para atraer al pequeño Dionisos a su círculo, los Titanes mueven una especie de sonajeros. Seducido por esos objetos brillantes, el niño camina hacia ellos y el círculo monstruoso se cierra sobre él. Todos juntos, los Titanes, asesinan a Dionisos; después de lo cual lo cuecen y lo devoran. Zeus, padre de Dionisos, fulmina a los Titanes y resucita a su hijo». Cf. ELIADE, M., Historia de las creencias y de las ideas religiosas, Vol. I, Cristiandad, Madrid 1978, 385.

43 Esta idea fue también asumida, años más tarde, por el sociólogo alemán Max Weber. En su análisis de la tradición judeocristiana, El judaísmo antiguo, subraya la tendencia bíblica a defender la causa de las víctimas. El sociólogo alemán no se preocupa por la relación con textos míticos que presenten analogías, por lo que no descubre la importancia que puede adquirir en el conjunto de la cultura. Su planteamiento es fundamentalmente socioeconómico. Para Weber, las mismas vicisitudes históricas del pueblo judío, explicarían su apología de 
cristianos es un Dios de las víctimas. Mientras que en las religiones paganas o primitivas el chivo expiatorio es culpable y el dios se identifica con la violencia.

Lo sorprendente, desde este punto de vista, es la actitud que toma Nietzsche ante tal descubrimiento. Él es capaz de distinguir las dos clases de religión. Pero opta por la religión de la violencia. Porque, la religión cristiana, piensa, es una religión surgida del resentimiento, que revela la injusticia del sufrimiento y muestra el absurdo de las multitudes dionisiacas de este mundo ${ }^{44}$. En cambio, lo dionisiaco es la vida misma en su fertilidad y repetición, en su tormento y su voluntad de aniquilar.

La postura de Nietzsche es admirable en su sinceridad, pero la historia ha mostrado hacia donde nos lleva un pensamiento de tal magnitud:

«El juicio de valor de Nietzsche es insostenible. Los esfuerzos piadosos para exonerar al pensador de las consecuencias de su propio pensamiento son erróneos. Es innegable que él mismo extiende el alcance de su juicio sobre cuestiones éticas y políticas, que sólo puede servir de estímulo a las peores aberraciones ideológicas.

Se pueden citar cientos de textos que muestran, más allá de toda duda, que la feroz testarudez de Nietzsche, en oponerse a la inspiración de la Biblia en favor de las víctimas, lógica e inexorablemente, le conduce hacia las actitudes cada vez más inhumanas de sus últimos años, a las que se adhiere, con las palabras desde luego más que con los hechos, con una fortaleza digna de mejor causa ${ }^{45}$.

Tras esta crítica de Girard, no sólo está el rechazo a su filosofía, sino a la misma influencia que tuvo el pensamiento de Nietzsche en muchos de los graves acontecimientos del siglo xx. Con todo, la pregunta que inevitablemente nos debemos hacer es por qué Nietzsche opta por esta actitud. Para hallar la respuesta recurriremos al papel de la revelación cristiana a la luz de la víctima expiatoria.

\section{LA MUerte DE Dios}

En la hipótesis de Girard, el mecanismo del chivo expiatorio se origina como medio de evitar la venganza, es decir, para contener la escalada definitiva de la violencia, canalizando ésta por medio de las religiones primitivas. Tanto las prohibiciones como los ritos cumplen el papel sociológico de establecer la distinción entre violencia legítima e ilegítima, de tal modo que es imposible un renacimiento de la violencia, salvo en los casos de nuevas reestructuraciones religiosas, cuando el orden cultural se haya agotado. Cuando la revelación

\footnotetext{
las víctimas, puesto que ha sido una pequeña nación víctima de las potencias que a lo largo de su existencia la han sometido y explotado.

44 Cf. GiRARD, R., «Dionysus...», 249-250 (20).

45 Ibid., 252 (22-23).
} 
cristiana se produce, poco a poco se va insertando en la sociedad una nueva conciencia, cuyo objetivo es la rehabilitación de las víctimas. Al mismo tiempo, desde un punto de vista sociológico, se produce una desacralización de las diversas dimensiones de lo real, análoga al proceso de las sociedades primitivas, pero sin retorno a nuevas sacralizaciones, pues el mecanismo se ha vuelto estéril con la revelación. Esta transformación, sin embargo, se realiza en un contexto paradójico, pues la interpretación de la religión imperante, la cristiana, sigue siendo sacrificial ${ }^{46}$.

Es decir, ya no se puede recurrir, como en las sociedades primitivas, al mecanismo del chivo expiatorio, pues las víctimas inocentes han sido rehabilitadas. Hecho que se debe al cristianismo. Sin embargo, la interpretación sacrificial del cristianismo, junto al cambio estructural de la sociedad, impide que se comprenda el papel de la violencia en el seno de las relaciones humanas, pues la violencia permanece inconsciente en la estructura debido a que sigue siendo heredera de lo sacrificial. La consecuencia es que la violencia se considera como un hecho aislado, dependiente exclusivamente del comportamiento humano y, por tanto, dominable por el hombre. Así, la violencia continúa actuando, aunque difiere la venganza final (la plena aniquilación), ya que hay elementos que parecen impedirle su plena actuación.

En este contexto debemos situar el pensamiento de Nietzsche. La interpretación que realiza del cristianismo responde a esa visión sacrificial que se mantenía. Nietzsche ha experimentado existencialmente los mecanismos de la dinámica del deseo, que en su fase metafísica conducen a la violencia. Sin embargo, la cultura de su época, precisamente gracias a la revelación, por desgracia pensaría Nietzsche, impide la acción de la violencia. El papel del cristianismo es oponer una moral no violenta, pero eso va contra lo que Nietzsche considera el ideal de la vida. Por tanto, acusa al cristianismo de ser una religión de resentidos. Una religión que mantiene una moral, cuyo fin es impedir el desarrollo de la voluntad de poder de los más fuertes.

Desde esta visión, no nos debe extrañar que Nietzsche quiera enfrentar a Dionisos frente al Crucificado. La vuelta a los dioses primitivos es el recurso a lo sagrado primitivo, a la violencia por excelencia.

Ahora bien, ¿es suficiente esta interpretación para justificar una posible comprensión del efecto expiatorio por parte de Nietzsche? Girard busca encontrar más argumentos que apoyen su hipótesis acerca del pensamiento del prusiano, y para ello va a recurrir a otro texto de Nietzsche, el más conocido acerca de Dios, el anuncio de su muerte:

«¿No habéis oído hablar de ese hombre loco que, en pleno día, encendía una linterna y echaba a correr por la plaza pública gritando sin cesar: "Busco a Dios, busco a Dios"? Como allí había muchos que no creían en Dios, su grito provocó la hilaridad. Qué ¿se ha perdido Dios?, decía uno. ¿Se ha perdido

46 Nos referimos al sentido de «sacrificio» de las religiones primitivas. Es decir, el cristianismo no habría integrado el valor no violento de la muerte de Jesús. 
como un niño pequeño?, preguntaba otro. ¿O es que estaba escondido? ¿Tiene miedo de nosotros? ¿Se ha embarcado? ¿Ha emigrado? Así gritaban y reían en confusión. El loco se precipitó en medio de ellos y los traspasó con su mirada. ¿Dónde se ha ido Dios?, yo os lo voy a decir, les gritó. ¡Nosotros le hemos matado, vosotros y yo! ¡Todos nosotros somos sus asesinos! Pero ¿cómo hemos podido obrar así? ¿Cómo hemos podido vaciar el mar? ¿Quién nos ha dado la esponja para borrar todo el horizonte? ¿Qué hemos hecho cuando hemos separado esta tierra de la cadena de su sol? ¿Adónde le conducen sus movimientos? ¿Lejos de todos los soles? ¿No caemos sin cesar? ¿Hacia delante, hacia atrás, de lado, de todos lados? ¿Todavía hay un arriba y abajo? ¿No erramos como a través de una nada infinita? El vacío ¿no nos persigue con su hálito? ¿No hace más frío? ¿No veis oscurecer cada vez más, cada vez más?... ¡Dios ha muerto! ¡Dios permanece muerto! ¡Y somos nosotros quienes le hemos dado muerte! ¿Cómo nos consolaremos, nosotros, asesinos entre los asesinos? Lo que el mundo poseía de más sagrado y más poderoso ha perdido su sangre bajo nuestro cuchillo. ¿Quién borrará de nosotros esta sangre? ¿Con qué agua podremos purificarnos? ¿Qué expiaciones, qué juegos nos veremos forzados a inventar? ¿La grandeza de este acto no es demasiado grande para nosotros? ¿No estamos forzados a convertirnos en dioses, al menos para parecer dignos? No hubo en el mundo acto más grandioso, y las generaciones futuras pertenecerán, por virtud de esta acción, a una historia más elevada de lo que fue hasta el presente toda la historia» ${ }^{47}$.

Este es, quizá uno de los textos más conocidos de Nietzsche y una de las citas paradigmáticas del ateísmo del siglo pasado. Sin embargo, la hermenéutica girardiana nos ofrece una lectura muy diferente del sentido del texto. En ningún caso se sale de las palabras del texto, simplemente se ciñe a interpretarlo a la luz de la hipótesis victimaria.

Según Girard, lo sorprendente del texto es que la descripción de la muerte de Dios recuerda al homicidio colectivo: "; $Y$ somos nosotros quienes le hemos dado muerte!». ¿Qué sentido tiene que Nietzsche diga esto? ¿No le hubiera bastado con hablar de la muerte sin apelar a un asesinato? Girard cree necesario considerar que Nietzsche ha intuido el mecanismo del chivo expiatorio y que, de algún modo, en este texto está efectuando ese mismo mecanismo con el Dios cristiano.

«El aforismo 125 funciona de la misma manera que el asesinato colectivo mismo, el cual está escondido detrás del tema de una muerte totalmente "natural" y pacífica, una muerte radicalmente no dramática, una muerte sin "historia". El texto sobre la muerte de Dios funciona como un asesinato más de Dios, en la misma medida en que el tema del asesinato permanece, sigue sin ser reconocido. Incluso esta epifanía textual de lo divino es el producto de un asesinato colectivo que los asesinos no son conscientes de haber cometido ${ }^{48}$.

Este «no-reconocimiento» se refiere al modo en que el texto se ha interpretado, nadie hasta ahora se había planteado que Nietzsche dijera otra cosa que

47 Nietzsche, F., La Gaya Ciencia, Libro III, 125, en: OC, V, 150-151.

48 GIRARD, R., «Dionysus...», 258 (30). 
el hecho de la muerte «natural» de Dios ${ }^{49}$. Sin embargo, el prusiano recurre explícitamente a todos los elementos necesarios en cualquier efecto expiatorio: acusa a todos de haber matado a Dios; recurre al papel de la violencia, "se ha desangrado a causa de nuestras puñaladas»; muestra la crisis social que causa indiferencias, ¿cómo hemos podido vaciar el mar? ¿Quién nos proporcionó la esponja para borrar todo el horizonte? ¿Qué hemos hecho cuando hemos roto la cadena que sujetaba esta tierra al sol? ¿Hacia dónde vamos ahora? ¿Lejos de todos los soles? ¿No caemos sin cesar? Adelante, hacia atrás, al lado, a todos lados. ¿Existe aún una altura y una profundidad? ¿No andamos errantes por una nada infinita? ¿No sentimos el soplo del vacío en nuestro rostro? ¿Acaso no hace más frío? ¿No se acercan unas noches cada vez más oscuras?; y exige los ritos que surgen tras una nueva sacralización, "¿quién nos limpiará de esta sangre?, ¿qué agua será capaz de lavarnos?, ¿qué expiaciones, qué juego ritual nos veremos obligados a inventar?» ${ }^{50}$.

La referencia al mecanismo es innegable. Pero, ¿cómo se ha de entender? Sea cual sea la intención de Nietzsche, algo que no podremos saber, lo que parece cierto es que el texto se puede relacionar con otros aspectos de su pensamiento. Si a Dios lo hemos matado, el mecanismo del chivo expiatorio nos diría que habrá una refundación religiosa, surgirán nuevos dioses sagrados. Y esto es lo que ocurre en el pensamiento de Nietzsche. Con la muerte o el asesinato del Dios cristiano, Nietzsche reclama la vuelta de nuevos dioses, el Dios de la violencia sagrada, Dionisos, o su equivalente, el hombre de la voluntad de poder.

¿Es casual que Nietzsche ruegue a Dionisos? En el contexto de nuestro análisis no parece serlo. Como también tiene sentido que revalorice la violencia, a fin de cuentas Nietzsche quiere volver a lo sagrado violento, característico de las sociedades primitivas. Y desde aquí, la historia tiene un solo sentido. La historia no puede ser lineal, la historia vuelve a ser eterno retorno, el ritmo de las sociedades estructuradas por lo sagrado violento, vuelta a lo precristiano y a lo presocrático.

Parece que a la luz del análisis de Girard, el ateísmo de Nietzsche no parece ser tal. Es, más bien, una vuelta a las religiones sagradas primitivas. Del mismo modo que el cristianismo se presentó como un ateísmo para las religiones paganas, en un mundo cristiano la nueva religión de Nietzsche es un ateísmo. Dios ha muerto, pero este cadáver es el del Dios cristiano hasta ahora vigente. No obstante, proclamemos un nuevo sustituto, reclamemos un nuevo chivo expiatorio que sea sacralizado y que nos devuelva a una nueva religión: « $i N o$ será imprescindible hacernos dioses para, sencillamente, alcanzar una actitud digna de él?». El nuevo Dios es el hombre, Nietzsche mismo, como vimos al hablar de su

49 Cf. ID, «La meurtre fondateur dans le pensée de Nietzsche», en: DumoucheL, P. (dir.), Violence et Vérité, Grasset, Paris 1985, 602-603.

50 Estos son elementos característicos y necesarios en el proceso del mecanismo del chivo expiatorio tal como es descrito por Girard. 
vida. «Nietzsche es víctima expiatoria, en lugar de Dios. Él es este loco que no puede anunciar la muerte de Dios sin exponerse, al menos simbólicamente ${ }^{51}$.

Sin embargo, el intento de Nietzsche, piensa Girard ${ }^{52}$, no puede triunfar. Porque él mismo ha colaborado en la revelación de un cristianismo que va contra la violencia arbitraria que ha fundado todas las religiones. El filósofo añade más conciencia a la revelación que viene actuando desde hace siglos. Pese a él mismo, pese a su empecinamiento por una vuelta a los ciclos rituales de las religiones primitivas, Nietzsche ha añadido un poco más de conocimiento a la revelación cristiana ${ }^{53}$.

\section{Conclusión}

Hemos descrito las claves desde la que Girard se acerca al pensamiento de Nietzsche, a los textos fundamentales del mismo. Habría que hacer dos objeciones a esta aproximación: en primer lugar, quizá pueda resultar oscuro o presuntuoso, por parte de nuestro autor, querer deducir de su «habilidad» para desembrollar textos conclusiones hasta ahora no percibidas en el pensamiento de Nietzsche; y en segundo lugar, hemos de matizar que el análisis de textos, desde la perspectiva del chivo expiatorio, puede llevar a la confusión entre la referencia a la realidad y el principio genético-estructural.

Respecto a lo primero, debemos recordar en favor de Girard que ninguna de las palabras por él citadas han sido inventadas, están dichas por Nietzsche. Si bien hay que reconocer que el francés tan sólo utiliza parte de las obras del pensador germano. Está por ver si es posible realizar una lectura del conjunto del pensamiento de Nietzsche desde la perspectiva expiatoria que propone Girard. En todo caso, eso no niega que la interpretación que realiza el francés está en los textos y que, desde una perspectiva histórica, la influencia de Nietzsche ha dado lugar a algunos de los acontecimientos más violentos del siglo xx.

Respecto a lo segundo, digamos que cuando nuestro autor habla del mecanismo en el origen de la historia se refiere primero a un acontecimiento real, pero de inmediato este acontecimiento se convierte en mecanismo genético, estructural y desestructurante, en tanto que internalizado de modo no consciente en toda la cultura. En nuestro mundo, el mecanismo no se puede ejercer hasta el final en un sentido real (no podemos hacer chivos expiatorios como en las sociedades sacrificiales), pero sigue permaneciendo como principio. Por eso Girard insiste en el valor que tiene cualquier texto que sea capaz de sugerir el mecanismo expiatorio: ya que posee tal potencia simbólica que ejerce una

51 GIRARD, R., Ibid., 608. «Nietzsche est victime expiatoire, á la place de Dieu. Il est cet insensé qui ne pas annoncer le meurtre de Dieu sans s'y exposer lui-même, au moins symboliquement».

52 Cf. Ibid., 611-613.

53 Cf. Ibid., 612-613. 
atracción desconocida (en su auténtica razón) para los que se acercan a él. La misma atracción que ejerce lo sagrado en el ámbito de lo religioso. Este poder simbólico inconsciente es el que funciona con el texto de Nietzsche: alrededor del cual han girado muchos de los intelectuales de nuestro tiempo. Detrás de este pensamiento nietzscheano está lo sagrado primitivo, en tanto que escondido y no plenamente revelado; en tanto que es, pero, al mismo tiempo, no lo es. Como pensaba Nietzsche, para leer su obra hay que «saber leer».

Supuesto esto, lo importante, desde nuestro punto de vista es extraer la línea de sentido que Girard está deduciendo de su análisis. No es casual que se detenga en Nietzsche, como tampoco lo fue que lo hiciera con Freud. Uno de los objetivos de Girard es superar la crítica religiosa de estos autores y poner de manifiesto la inconsistencia de la modernidad a través de ellos. Por tanto, nuestro papel es ver cómo cree conseguir esto.

En el pensamiento de la sospecha es común la crítica de la religión bajo la acusación de algún modo de violencia, ejercida fundamentalmente por un Dios terrible y, en la mayoría de los casos, por sus representantes sustitutorios. En Nietzsche esta crítica es más feroz, si cabe, porque está cargada de afectividad. Esta emotividad existencial y su genio intelectual confieren a Nietzsche una capacidad de profundización en sus análisis que pocos pensadores han mostrado hasta ahora.

Nietzsche sitúa la crítica de la religión en una perspectiva ética al enfrentar la moral de los esclavos, característica de lo judeocristiano, frente a la moral del superhombre. Sin embargo, el análisis afectivo no está desechado, para Nietzsche las religiones son el resultado de los resentimientos de los débiles, que incapaces de triunfar en este mundo apelan al más allá para superar a los más fuertes. La religión en Nietzsche, por tanto, brota de la «venganza» y se sostiene sobre ella.

El parentesco con el pensamiento de Girard es evidente. Si algo demuestra el mecanismo del chivo expiatorio es que la religión tiene su origen histórico en la venganza. Girard alaba, como vimos en el apartado anterior, lo cerca que está Nietzsche de los mecanismos victimarios. Sin embargo, no puede dejar de reprocharle el haber sido incapaz de salirse de ellos. Nietzsche es heredero de la visión sacrificial del cristianismo. No tenemos más que adentrarnos en sus críticas a la Iglesia y a sus representantes ${ }^{54}$. Probablemente muy merecidas. En cambio, también capta el elemento no sacrificial, al mostrar que el cristianismo defiende a los débiles. A pesar de esto, Nietzsche no opta por profundizar en este último factor, sino que decide invertirlo todo, la religión, la moral y los valores. Frente a la defensa de los débiles, él quiere proteger a los más fuertes; frente a la religión de la no-violencia, él opta por la religión de la violencia; frente al amor a los demás, él opta por el yo absoluto.

Girard aceptó la sospecha lanzada contra la religión por Nietzsche y reconstruye su hipótesis, partiendo del mismo presupuesto que el filósofo. Para

54 Cf. Nietzsche, F., Genealogía de la moral, OC, VII. 
superar la sospecha lanzada por la filosofía es necesario remontarse también a las fuentes de la religión. Girard hace una nueva genealogía, que incluye la crítica nietzscheana, pero al mismo tiempo cree superarla. Reconoce la violencia presente en la religión, pero cree que no es aceptable la solución propuesta por el prusiano. Desde el punto de vista expiatorio, Nietzsche no ha conseguido salir de la estructura sacrificial en la que el hombre vive desde que se constituyó como tal. Es el autor que más cerca está de revelarla, el que más contribuye a ponerla de manifiesto. Pero acaba cayendo en ella, pues elige realizar un nuevo pensamiento expiatorio. Aunque por ser más violento, es al mismo tiempo más revelador, porque la violencia está menos escondida.

Nietzsche es el reverso de la moneda reveladora, cuya cara es Dostoyevski. Ambos pasan por la misma crisis relacional, pero la actitud que toma cada uno es opuesta, Dostoyevski opta por el rechazo de la violencia y por aceptar el amor, que le lleva a la religión; Nietzsche, en cambio, opta por la voluntad de poder.

La deducción que hacemos del planteamiento de Girard se acerca a otras críticas realizadas con anterioridad al pensamiento de Nietzsche, en particular desde perspectivas cristianas. Pero consideramos que si bien es verdad que el resultado es similar, en el caso de Girard la crítica se realiza desde un ángulo tan singular que le confiere mayor credibilidad. Nietzsche no es un filósofo al uso, su pensamiento parte desde una experiencia personal particular y acercarse a él con las armas y el lenguaje filosófico quizá pueda ser reduccionista. Las categorías filosóficas parecen no ser las más adecuadas para profundizar en su comprensión ${ }^{55}$. Su análisis de Nietzsche está más cerca del psicoanálisis freudiano que de un sistema filosófico.

Por consiguiente, nuestro autor puede alcanzar en Nietzsche una compresión del hombre que otros no han podido alcanzar. El análisis del pensamiento de Nietzsche, a partir de la experiencia personal, descubre en éste la expresión de la propia voluntad del filósofo que quiere afirmarse en su sí, pese a poder ser afirmación de la violencia. Así, el enfoque realizado por Girard muestra que, en la crítica fundamental de Nietzsche a la religión tradicional, se inserta un modo de comprensión de lo religioso en su sentido más sacrificial. Nietzsche identifica al creyente con una voluntad resentida, reactiva, que impide al auténtico hombre libre afirmarse en su voluntad positiva, que es voluntad de poder. Pero esta identificación, siendo mayoritariamente cierta de los cristianos de su época, no deja de ser una reducción. También en la historia ha habido creyentes, cuya vivencia de la religiosidad les ha conducido a la afirmación de la vida o, a lo que el mismo Girard llamaría, una experiencia no-sacrificial de la fe. Este aspecto reductivo hace pensar que no es un supuesto necio la acusación a Nietzsche de concebir la religión desde su propio resentimiento. De esta suerte, tienen sentido todas las homologías realizadas por Girard a propósito

55 Cf. Valadier, P., Nietzsche y la crítica del Cristianismo, 551-555. 
de los símbolos relacionales surgidos entre Wagner (Dionisos) - Nietzsche (el Crucificado) ${ }^{56}$.

Sin embargo, hay un factor positivo en Nietzsche que es necesario resaltar. Cuando él se opone al cristianismo, está queriendo superar una visión eticista de la religión que ha llevado al hombre a una escisión en sí mismo, que en vez de abrirle a la creatividad de la libertad, le conduce al miedo y a una voluntad del resentimiento. La crítica de Nietzsche no puede menos que recordarnos al Gran Inquisidor de Dostoyevski, el cual prefiere imponer la esclavitud a los cristianos antes que ofrecerles la libertad dada por el mismo Jesús, aunque estos se arriesguen a la equivocación. Es evidente que Nietzsche prefiere esa libertad. Girard podría estar de acuerdo con esta crítica y con esta escisión planteada por Nietzsche. La escisión, pensaría, viene descrita por la estructura expiatoria y su tendencia a la expulsión. Pero Girard insistiría en su creencia de que la dificultad no está ni en el cristianismo, ni en la moral, que podrían convertirse en chivos expiatorios del pensamiento de Nietzsche. La dificultad está en superar una estructura excluyente. Sólo desde un cambio en esta visión, el hombre puede reordenar su vida y su relación con los otros y el Otro desde la libertad. Una libertad que asuma la finitud humana y no que exija un poder creativo, que podría arrastrar al hombre, de nuevo, a la violencia sin fin.

Facultad de Teología de Granada

Pablo Ruiz Lozano

Departamento de Filosofía

pabloruiz@probesi.org

[Artículo aprobado para publicación en noviembre de 2013]

56 Cf. Girard, R., Dionysus. 